\title{
Estimation of selected properties of forest soils using near-infrared spectroscopy (NIR)
}

\begin{abstract}
The study was focused on the application of near-infrared spectroscopy (NIR) as a tool for evaluation of selected properties of forest soils. We analysed 144 soil samples from the topsoil of nine plots located in southern Poland. Six plots were established under pine stands, and three plots under oak stands. The NIR measurements were performed using Antharis II FT scanner. On the basis of the spectrum files obtained from scanning of 96 samples and the measurement results obtained for selected properties of the soil samples, we developed a calibration model. The model was validated using 48 independent samples. We attempted to estimate the following properties of forest soils: $\mathrm{pH}, \mathrm{C}: \mathrm{N}$ ratio, the organic carbon content $\left(\mathrm{C}_{\mathrm{t}}\right)$, total nitrogen $\left(\mathrm{N}_{\mathrm{t}}\right)$, clay content (Clay), base cation content (BC), cation exchange capacity (CEC) and total acidity (TA). We conclude that estimation of soil properties using NIR method can be applied as additional (to laboratory analysis) or initial assessment of soil quality. Our results also suggest that forest species composition may affect the mathematical model applied to NIR spectra analysis, however, this hypothesis needs some of further investigations.
\end{abstract}

Keywords: forest soil, near infrared, NIR, soil quality index, soil properties

\section{INTRODUCTION}

Near-infrared (NIR) technique is an alternative to the time-consuming and expensive laboratory measurements. Low costs of measurement are the result of minimal requirements for sample preparation and no need for laboratory analysis. This is a non-invasive method that allows to estimate a number of soil properties on the basis of single spectrum shape analysis obtained within several seconds (Ben-Dor and Banin 1995, Chang et al. 2001, Islam et al. 2003, Shepherd and Walsh 2002).

Potentially, NIR technique can be also used as a tool to facilitate the determination of the soil properties required for the calculation of the Soil Quality Index (SQI) (Brożek et al. 2010). SQI is a modern method of diagnosing a forest site quality, based on selected soil properties.

With the NIR technique used, the results obtained are only an estimation of the real values, naturally prone to error. Therefore, it is necessary to scan a larger number of samples to obtain an average value close to the one obtained from laboratory measurements. Moreover, it is little known if the model parameters can be modified by the species composition of the forest stand, which is very important for developing such models for forest soils (Ben-Dor and Banin 1995, Chodak et al. 2007, Stenberg et al. 2010).
The aim of the present study was to investigate the applicability of NIR spectroscopy for the evaluation of selected properties of forest soils, particularly these required to calculate the SQI. Properties of NIR spectra were related to soil properties that are commonly used to assess the quality of forest soil. We also considered the potential impact of two forest stands ((Scots pine (Pinus sylvestris L.) and common oak (Quercus robur $L$.)) composition on the results.

\section{MATERIALS AND METHODS}

Nine investigation plots were located in the areas of three forest divisions (Dąbrowa Tarnowska, Krzeszowice and Niepołomice) located in southern Poland. A detailed description of the plots was presented by Gruba (2012), and Gruba and Mulder (2015). These plots were established under pine and oak forest stands, on soils developed from different types of parent material (Table 1). Samples were collected at each plot from top $10 \mathrm{~cm}$ of mineral soil, at regular grid of $4 \times 4 \mathrm{~m}$ (16 samples per plot).

In this study, we employed as reference the previous results of laboratory analysis of eight selected soil properties, such as $\mathrm{pH}$, the total content of carbon $\left(\mathrm{C}_{t}\right)$ and nitrogen $\left(\mathrm{N}_{t}\right), \mathrm{C}: \mathrm{N}$ ratio, the content of clay and exchangeable bases (BC), cation exchange capacity (CEC) and total acidity (TA) (Table 2), 
TABLE 1. Characteristics of the investigation plots

\begin{tabular}{|c|c|c|c|}
\hline $\begin{array}{l}\text { Plot } \\
\text { name }\end{array}$ & $\begin{array}{l}\text { Location } \\
\text { (forest division) }\end{array}$ & $\begin{array}{l}\text { Parent } \\
\text { material }\end{array}$ & $\begin{array}{l}\text { Forest stand age } \\
\text { (years) }\end{array}$ \\
\hline Pine 1 & $\begin{array}{l}\text { Bratucice village } \\
\text { (Dabrowa } \\
\text { Tarnowska) }\end{array}$ & Sand & $\begin{array}{l}\text { pine } 80 \\
\text { Pinus sylvestris L. }\end{array}$ \\
\hline Pine 2 & $\begin{array}{l}\text { Bratucice village } \\
\text { (Dabrowa } \\
\text { Tarnowska) }\end{array}$ & Sand & $\begin{array}{l}\text { pine } 70 \\
\text { Pinus sylvestris L. }\end{array}$ \\
\hline Pine 3 & $\begin{array}{l}\text { Kłaj village } \\
\text { (Niepołomice) }\end{array}$ & Sand & $\begin{array}{l}\text { pine } 50 \\
\text { Pinus sylvestris L. }\end{array}$ \\
\hline Pine 4 & $\begin{array}{l}\text { Kłaj village } \\
\text { (Niepołomice) }\end{array}$ & Sand & $\begin{array}{l}\text { pine } 70 \\
\text { Pinus sylvestris L. }\end{array}$ \\
\hline Pine 5 & $\begin{array}{l}\text { Kopce village } \\
\text { (Krzeszowice) }\end{array}$ & Loess & $\begin{array}{l}\text { pine } 90 \\
\text { Pinus sylvestris L. }\end{array}$ \\
\hline Pine 6 & $\begin{array}{l}\text { Kopce village } \\
\text { (Krzeszowice) }\end{array}$ & Loess & $\begin{array}{l}\text { pine } 90 \\
\text { Pinus sylvestris L. }\end{array}$ \\
\hline Oak 1 & $\begin{array}{l}\text { Bratucice village } \\
\text { (Dabrowa } \\
\text { Tarnowska) }\end{array}$ & Loess & $\begin{array}{l}\text { oak } 80 \\
\text { Quercus robur L. }\end{array}$ \\
\hline Oak 2 & $\begin{array}{l}\text { Bratucice village } \\
\text { (Dabrowa } \\
\text { Tarnowska) }\end{array}$ & Loess & $\begin{array}{l}\text { oak } 85 \\
\text { Quercus robur L. }\end{array}$ \\
\hline Oak 3 & $\begin{array}{l}\text { Kłaj village } \\
\text { (Niepołomice) }\end{array}$ & Loess & $\begin{array}{l}\text { oak } 70 \\
\text { Quercus robur L. }\end{array}$ \\
\hline
\end{tabular}

presented by Gruba and Mulder (2015). NIR scanning was performed using Antharis II FT scanner. Soil samples were placed in glass tube and scanned in range from 1000 to $2500 \mathrm{~nm}$. The scanner does not require any additional adjustment. Next, we performed analysis and processing of spectra by means of TQ Analyst 8 software. To calibrate the model, we used the spectrum files of 96 soil samples. In order to verify the accuracy and reliability of the developed models, we performed a validation test for 48 selected schematically chosen spectra (every third file) that had not been previously used to calibrate the model. After multiple test calibrations, we selected the settings which proved to yield the highest correlation coefficients for the studied soil properties. The best results were obtained by calibrating the full-length ranges of spectra (1000$2500 \mathrm{~nm}$ ) and using the PLS (partial least square) regression model. Then we chose the derivative as well as the type and size of smoothing filters. The quality of calibration and validation of soils from pine and oak forest stands was expressed by the coefficient of determination of calibration $\left(\mathrm{R}^{2} \mathrm{C}\right)$ and coefficient of determination of validation $\left(R^{2} V\right)$ (Table 2$)$.

\section{RESULTS AND DISCUSSION}

To illustrate the differences between the results of NIR analysis of different soil samples, in Figure 1 we showed the spectra of 30 selected soil samples which were divided into three groups by their content of $\mathrm{C}_{\mathrm{t}}$ : small (0 to $1 \%)$, medium (1 to10\%) and high (20 to $30 \%$ ). Shapes of the spectra of samples with low and

TABLE 2. Statistical characteristics of the studied properties of soils

\begin{tabular}{|c|c|c|c|c|c|c|c|c|}
\hline \multirow{2}{*}{$\begin{array}{l}\text { Soil } \\
\text { properties* }\end{array}$} & \multirow[t]{2}{*}{ Unit } & \multirow{2}{*}{$\begin{array}{l}\text { Forest } \\
\text { stand }\end{array}$} & \multirow[t]{2}{*}{$\mathrm{R}^{2} \mathrm{C}$} & \multirow[t]{2}{*}{$\mathrm{R}^{2} \mathrm{~V}$} & \multicolumn{2}{|c|}{ Measured values } & \multirow{2}{*}{$\frac{\text { Calculated values }}{\text { mean (max-min) }}$} & \multirow[t]{2}{*}{$\mathrm{p}$} \\
\hline & & & & & $\mathrm{n}$ & mean (max-min) & & \\
\hline \multirow[t]{2}{*}{$\mathrm{pH}$} & - & pine & 0.91 & 0.66 & 32 & $3.1(3.7-2.6)$ & $3.1(3.4-2.7)$ & NS \\
\hline & & oak & 0.15 & 0.19 & 16 & $3.3(3.6-3.0)$ & $3.3(3.6-2.5)$ & NS \\
\hline \multirow[t]{2}{*}{$\mathrm{C}: \mathrm{N}$} & - & pine & 0.86 & 0.76 & 32 & $26(44-15)$ & $26(37-16)$ & NS \\
\hline & & oak & 0.55 & 0.19 & 16 & $21(26-18)$ & $21(35-14)$ & NS \\
\hline \multirow[t]{2}{*}{$\mathrm{C}_{\mathrm{t}}$} & $\mathrm{mg} \cdot \mathrm{g}^{-1}$ & pine & 0.80 & 0.03 & 32 & $31.5(55.6-13.3)$ & $58.7(38.2-12.9)$ & $<0.25$ \\
\hline & & oak & 0.48 & 0.22 & 16 & $25.6(46.3-18.1)$ & $24.9(53.9-14.5)$ & NS \\
\hline \multirow[t]{2}{*}{$\mathrm{N}_{\mathrm{t}}$} & $\%$ & pine & 0.90 & 0.59 & 32 & $0.13(0.30-0.06)$ & $0.15(0.24-0.04)$ & 0.005 \\
\hline & & oak & 0.59 & 0.26 & 16 & $0.12(0.20-0.08)$ & $0.12(0.18-0.08)$ & NS \\
\hline \multirow[t]{2}{*}{ Clay } & $\mathrm{g} \cdot \mathrm{kg}^{-1}$ & pine & 0.95 & 0.57 & 32 & $41(111-10)$ & $37(113-1)$ & NS \\
\hline & & oak & 0.67 & 0.21 & 16 & $36(50-10)$ & $36(51-11)$ & $<0.5$ \\
\hline \multirow[t]{2}{*}{$\mathrm{BC}$} & $\mathrm{cmol}_{(+)} \mathrm{kg}^{-1}$ & pine & 0.60 & 0.56 & 32 & $0.86(3.10-0.22)$ & $0.88(1.88-0.15)$ & $\mathrm{NS}$ \\
\hline & & oak & 0.04 & -0.06 & 16 & $0.55(0.77-0.25)$ & $0.60(0.82-0.23)$ & NS \\
\hline \multirow[t]{2}{*}{ CEC } & $\mathrm{cmol}_{(+)} \mathrm{kg}^{-1}$ & pine & 0.87 & 0.29 & 32 & $14.3(22.8-8.1)$ & $15.6(20.2-6.8)$ & $<0.05$ \\
\hline & & oak & 0.34 & 0.34 & 16 & $9.8(15.7-7.1)$ & $10.1(23.2-5.1)$ & NS \\
\hline \multirow[t]{2}{*}{$\mathrm{TA}$} & $\mathrm{cmol}_{(+)} \mathrm{kg}^{-1}$ & pine & 0.83 & 0.40 & 32 & $14.8(19.8-10.0)$ & $16.0(21.2-10.1)$ & NS \\
\hline & & oak & 0.43 & 0.17 & 16 & $10.8(15.2-8.4)$ & $11.2(21.6-8.2)$ & NS \\
\hline
\end{tabular}

* The properties were presented Gruba and Mulder (2015).

Explanation: $\mathrm{C}: \mathrm{N}$ - carbon to nitrogen ratio; $\mathrm{C}_{\mathrm{t}}-$ total carbon; $\mathrm{N}_{\mathrm{t}}-$ total nitrogen; Clay - clay; $\mathrm{BC}$ - base cations; CEC - cation exchange capacity; $\mathrm{TA}$ - total acidity; $\mathrm{R}^{2} \mathrm{C}$ - coefficient of determination for calibration; $\mathrm{R}^{2} \mathrm{~V}$ - coefficient of determination for validation; $\mathrm{n}$ - number of samples; max - maximum values; min - minimum values; $\mathrm{p}$ - significance level; NS - no significant differences $\mathrm{p}>0.05$. 
FIGURE 1.

Set of sample

NIR spectra

from the soil

samples with

low, medium and

high total carbon

$\left(\mathrm{C}_{\mathrm{t}}\right)$ content
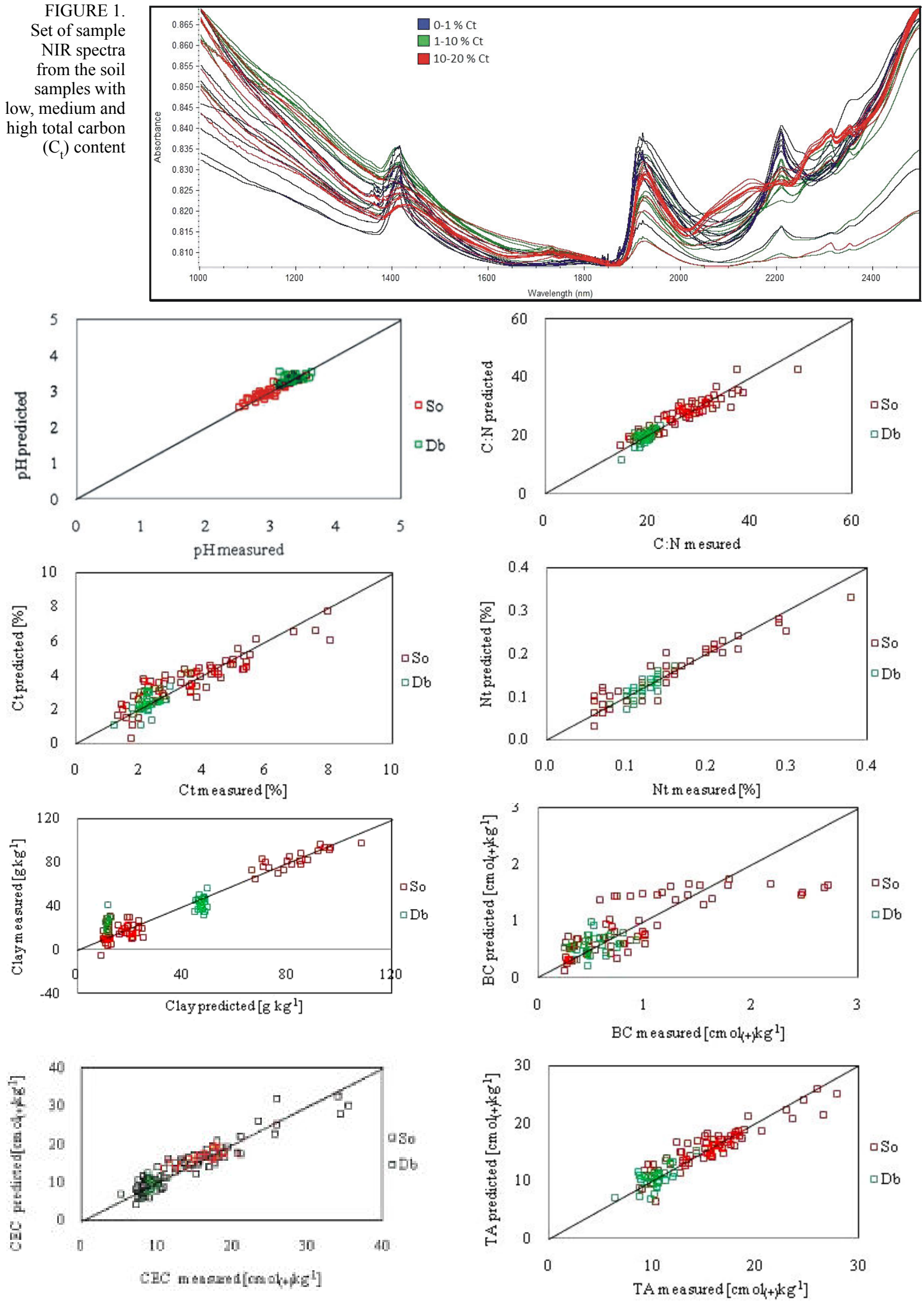

FIGURE 2. The results of calibration for investigated soil properties. Note that in some cases the predicted values could be negative 
medium content of $\mathrm{C}_{\mathrm{t}}$ were very similar: the highest peaks of absorbance were observed at the wavelengths of about 1400, 1900 and $2200 \mathrm{~nm}$. In contrast, the spectrum of soils with a high $C_{t}$ content showed highest absorption peaks at wavelengths of about 2150 and $2300 \mathrm{~nm}$.

The calibration results are shown in Figure 2. Relatively good calibration results expressed by $\mathrm{R}^{2} \mathrm{C}$ were obtained for $\mathrm{pH}, \mathrm{C}: \mathrm{N}, \mathrm{C}_{\mathrm{t}}, \mathrm{N}_{\mathrm{t}}$, Clay, CEC and TA. The lowest quality results were achieved as a result of the $\mathrm{BC}$ calibration. Models developed for soils of pine stands were characterized by a high degree of accuracy (reflected by much higher $\mathrm{R}^{2} \mathrm{C}$ ) compared to the models for soils oak stands.

Results of the validation are presented in Table 2. Relatively similar values were obtained for: $\mathrm{pH}, \mathrm{C}: \mathrm{N}$ and TA. Differences between measured and calculated values were not statistically significant (Table 2). Validation of $\mathrm{C}_{\mathrm{t}}, \mathrm{N}_{\mathrm{t}}$, Clay and CEC yielded moderatequality results, whilst the worst results were achieved for BC. Low quality of the validation results, particularly for $\mathrm{BC}$, confirmed the conclusions previously reported by some researchers who believed that NIR was not understood well enough to fully replace laboratory methods (e.g. Cozzolino and Morón 2006, Ludwig et al. 2002) and, moreover, required a relatively large range of data to obtain higher values of $\mathrm{R}^{2}$.

Relatively good validation results for C:N and TA encourage us to suggest the use of NIR as a tool to facilitate the determination of soil properties necessary to calculate the SQI (Brożek 2007). However, for the SQI to be reliably calculated on the basis of results obtained with the NIR, further work would be required to improve estimation of $\mathrm{BC}$ and Clay.

Lower quality of the validation is also probably the result of a relatively narrow range of data. Low variability of the data is related to homogeneity of soil samples that originate from the same soil horizon (mostly A). Therefore, there is a need to perform a large number of NIR measurements and create libraries of files in order to obtain a wide range of data on different properties.

The species composition of forests stand had an obvious impact on the chemical and physical properties of soil (Gruba et al. 2013). However, our results suggest that the tree species investigated (pine and oak) had no or weak potential impact on the parameters of the models. Therefore, the influence of forest stand on NIR analyses and modeling requires further investigations on larger data sets.

\section{CONCLUSIONS}

1. We conclude that estimation of soil properties using NIR method can be only applied as a support for the laboratory analysis or as a method of initial assessment of soil quality. In some cases the results obtained from a single sample scanning can be disappointing (e.g. negative values). We suggest that the evaluation of soil properties should be based on large number of spectrum samples. Therefore, there is a need to create a data base (a library) that covers a wide range of soil properties.

2 . The species composition of forest stands definitely affect soil properties, however, our results suggest the need of further investigations on impact of tree species on the mathematical model applied to NIR spectra analysis.

\section{REFERENCES}

Ben-Dor E., Banin A., 1995. Near-infrared analysis as a rapid method to simultaneously evaluate several soil properties. Soil Science Society of America Journal 59(2): 364-372.

Brożek S., 2007. Liczbowa wycena ,jakości” gleb - narzędzie w diagnozowaniu siedlisk leśnych. Sylwan 2: 35-42.

Brożek S., Gruba P., Lasota J., Zwydak M., Wanic T., Pacanowski P., Błońska E., Różański W., 2010. Opracowanie indeksów jakości gleb dla naturalnych siedlisk leśnych nizin i wyżyn Polski i ich zastosowanie w gospodarce leśnej jako narzędzia w zachowaniu i odtwarzaniu różnorodności lasów. Studia i Materiały CEPL w Rogowie 2(25): 292-302.

Chang C.W., Laird D.A., Mausbach M.J., Hurburgh C.R., 2001. Near-infrared reflectance spectroscopy - principal components regression analyses of soil properties. Soil Science Society of America Journal 65(2): 480-490.

Chodak M., Niklińska M., Beese F., 2007. Near-infrared spectroscopy for analysis of chemical and microbiological properties of forest soil organic horizons in a heavy-metalpolluted area. Biology Fertility of Soils 44: 171-180.

Cozzolino D., Morón A., 2006. Potential of near-infrared reflectance spectroscopy and chemometrics to predict soil organic carbon fractions. Soil Tillage Research 85: 78-85.

Gruba P., 2012. Zależności pomiędzy wybranymi właściwościami jonowymiennymi gleb leśnych oraz ich zmiany pod wpływem drzewostanów. Zeszyty Naukowe Uniwersytetu Rolniczego im. Hugona Kołłątaja w Krakowie 366: ss.70.

Gruba P., Mulder J., 2015. Tree species affect cation exchange capacity (CEC) and cation binding properties of organic matter in acid forest soils. Science of the Total Environment 511: 655-662.

Gruba P., Pacanowski P., Mulder J., 2013. Factors influencing spatial heterogeneity of $\mathrm{pH}$ in forest soils on the example of luvisols with marlstone underlayer. Sylwan 157: 149-157.

Islam K., Singh B., McBratney A., 2003. Simultaneous estimation of several soil properties by ultra-violet, visible, and near- 
infrared reflectance spectroscopy. Australian Journal of Soil Research 41: 1101-1114.

Ludwig B., Khanna P.K., Bauhus J., Hopmans P., 2002. Near infrared spectroscopy of forest soils to determine chemical and biological properties related to soil sustainability. Forest Ecology and Management 171: 121-132.
Shepherd K.D., Walsh M.G., 2002. Development of Reflectance Spectral Libraries for Characterization of Soil Properties. Soil Science Society of America Journal 66: 988-998.

Stenberg B., Rossel R.A.V., Mouazen A.M., Wetterlind J., 2010. Visible and Near Infrared Spectroscopy in Soil Science. Advances in Agronomy 107: 163-215.

Received: March 18, 2016

Accepted: June 1, 2016

\title{
Ocena wybranych właściwości gleb leśnych za pomocą spektroskopii bliskiej podczerwieni (NIR)
}

\begin{abstract}
Streszczenie: Badania dotyczyły zastosowania spektroskopii bliskiej podczerwieni (NIR) do oceny wybranych właściwości gleb leśnych. Analizie poddano 144 próbki gleb pochodzących z dziewięciu powierzchni badawczych, zlokalizowanych w południowej Polsce. Sześć powierzchni zostało założonych pod drzewostanami sosnowymi, a trzy pod drzewostanami dębowymi. Pomiary NIR wykonano aparatem Antharis II FT. W oparciu o uzyskane widma oraz oznaczone wcześniej właściwości gleb (pH, całkowitej zawartości węgla $\left(\mathrm{C}_{\mathrm{t}}\right)$, azotu $\left(\mathrm{N}_{\mathrm{t}}\right)$, iłu $(\mathrm{CL})$, sumy kationów zasadowych $(\mathrm{BC})$, pojemności wymiany kationów (CEC) i kwasowości hydrolitycznej (TA) przeprowadzono kalibrację modelu obliczeniowego (96 próbek), a następnie jego walidację (48 próbek). W badaniu zastosowano technikę NIR do oszacowania następujących właściwości gleb leśnych: $\mathrm{pH}$, wartości stosunku C:N, zawartości $\mathrm{C}_{\mathrm{t}}, \mathrm{N}_{\mathrm{t}}, \mathrm{CL}, \mathrm{BC}, \mathrm{CEC}$ i TA. Uzyskane wyniki sugeruja, że estymacja właściwości gleb przy zastosowaniu techniki NIR może być zastosowana jako dodatkowa technika towarzysząca tradycyjnym metodom laboratoryjnym lub w celu wstępnej oceny właściwości gleb. Badania dotyczące wpływu drzewostanów na parametry modelu nie dały również jednoznacznej odpowiedzi. Stąd zalecane są dalsze badania.
\end{abstract}

Słowa kluczowe: bliska podczerwień, gleby leśne, NIR siedliskowy indeks glebowy, właściwości gleb 